\title{
Contribution of zooplankton associated with detritus to sediment trap 'swimmer' carbon in Monterey Bay, California, USA
}

\author{
Deborah K. Steinberg ${ }^{1, *}$, Cynthia H. Pilskaln ${ }^{2}$, Mary W. Silver ${ }^{3,4}$ \\ ${ }^{1}$ Bermuda Biological Station for Research, Inc., Ferry Reach GE 01, Bermuda \\ ${ }^{2}$ School of Marine Sciences, University of Maine, Orono, Maine 04469, USA \\ ${ }^{3}$ Institute of Marine Sciences, University of California, Santa Cruz, Californía 95064, USA \\ ${ }^{4}$ Monterey Bay Aquarium Research Institute, Moss Landing, California 95039, USA
}

\begin{abstract}
A major food source to the deep sea is thought to be organic detritus derived ultimately from surface production. Much of the detritus is lost as it settles, presumably both to microbial and to metazoan consumers. In the last several decades much research has been devoted to quantifying this vertical particle flux using sediment traps. In processing samples from sediment traps 'swimmers', i.e. zooplankton that are thought to actively enter sediment traps and artificially augment the trap contents are traditionally removed. However, some zooplankton caught in the traps are likely to be genuine associates and decomposers of detritus and thus similar to microorganisms on detritus which are, mostly for practical reasons, included in the 'particle flux' We determine what proportion of the swimmer assemblage is detrital associates, and how these detntal associates may affect mesopelagic particle flux measurements, by comparing zooplankton taxa removed from sediment trap samples obtained at $450 \mathrm{~m}$ depth in Monterey Bay, California, with taxa observed and collected on large detrital particles (giant larvacean houses) in situ with a submersible ROV (remotely operated vehicle). Trap swimmer composition in Monterey Bay was diverse. Calanoid copepods and adult Hyperia mesudarium amphipods contributed the most to total swimmer carbon; and juvenile hyperiid amphipods, calanoid copepods, and Oncaea sp. copepods were the most numerous of all groups. Polychaete larvae were also a conspicuous part of the assemblage. The entire swimmer component averaged $24 \%$ of total trap POC $(=$ detrital + swimmer C) in traps, but only $1.5 \%$ of total trap POC was due to those we consider detrital associates (e.g. copepods: Oncaea spp., Microsetella spp., and Scopalatum sp.; polychaetes; juvenile hyperiid amphipods). Thus zooplankton on detritus are a relatively small percentage of the POC flux in these traps, and their removal introduces little ambiguity to trap flux measurements in this area. Important impediments to understanding the contribution of such zooplankton are our limited knowledge of the zooplankton decomposer community at depth, their different contributions in low versus high flux environments, and the behavior of zooplankton on encountering a trap.
\end{abstract}

KEY WORDS: Sediment trap Swimmers Detritus Zooplankton Monterey Bay Larvacean

\section{INTRODUCTION}

The sinking of particulate matter is an important component of the ocean carbon cycle and integral to our understanding of long-term changes in atmospheric $\mathrm{CO}_{2}$. This link of surface primary production with deeper waters has important implications for deep-sea food webs and the regeneration and cycling

•E-mail: debbie@bbsr.edu of other elements. Sediment traps, either free-floating or moored collectors, are regularly used to measure vertical particle flux in the ocean. However, the traps collect not only non-living particles but a range of apparently healthy zooplankton and fish. The presence of these animals poses significant problems in measuring particle flux.

Metazoan zooplankton in traps are labeled 'swimmers' and are thought to actively enter traps, sometimes significantly augmenting the mass of particles 
there (Knauer et al. 1979, Lee et al. 1988, Karl \& Knauer 1989, Silver et al. 1991). They traditionally have been removed from trap samples and not included in mass measurements of the particle flux. Crustaceans are among the most easily noticed swimmers and are removed when possible. Other more cryptic organisms, such as siphonophores and larvaceans, are more difficult to handle and are often included in total carbon flux estimates (Michaels et al. 1990)

Of the organisms caught in sediment traps, some are true intruders or contaminants, and some are likely to be genuine associates of detritus. Bacteria and microorganisms that are associated with detritus and derive their energetic needs from detritus are always included in particulate carbon measurements and are thus considered part of the mass flux (Silver \& Gowing 1991). Detritus is assumed to be a major food source for zooplankton in the deep sea, and sinking particles may provide habitat or shelter for some zooplankton. Recent work in Monterey Bay demonstrates that some zooplankton taxa are closely and consistently associated with large, detrital particles at midwater depths (Steinberg et al. 1994, 1997) and that some of the associated copepods consume this detritus (Steinberg 1995). Some of these zooplankton thus represent a decomposer community that converts the detrital matrix into living tissue still associated with the particle, analogous to the microbial decomposers. Thus, a portion of the zooplankton community on sinking detritus (those that attach for the 'lifetime' of a particle and do not return to their depth of origin) can legitimately be included as part of the flux, for the same reasons that bacteria and other microorganisms are.

In the present study we examine whether the zooplankton found in traps are actually close associates of detritus rather than individuals that have independently entered traps - i.e. true 'swimmers'. We examine zooplankton removed from moored sediment traps deployed in the same area (and time) where we had the unique opportunity to collect zooplankton associated with large particles (giant larvacean houses) using a submersible ROV (remotely operated vehicle). The ROV enabled us to distinguish particle-associated taxa from those that are free-living (Steinberg et al. 1994). Silver et al. (in press) have shown that particle composition of the giant larvacean houses is similar to that found in the trap arrays in our study area. By comparing taxa observed and collected on particles in situ (via the ROV) with those swimmers removed from sediment traps, we determine to what extent detritusassociated zooplankton affect estimates of midwater particle flux. This same comparison allows us to determine if traps are useful collectors for studying these larger members of the deep-sea detrital community.

\section{MATERIALS AND METHODS}

Sediment trap samples were obtained from Monterey Bay, California, USA, with a cone-shaped, baffled trap $\left(0.05 \mathrm{~m}^{2}\right.$ surface collection area) produced by AMI (Aquatic Monitoring Institute, USA) (Anderson 1977). The trap was deployed at an average depth of $450 \mathrm{~m}$ from August 1987 through November 1992 at a $650 \mathrm{~m}$ deep site at the Monterey Bay Aquarium Research Institute Stn S1 mooring $\left(36^{\circ} 44.333^{\prime} \mathrm{N}, 122^{\circ} 02.416^{\prime} \mathrm{W}\right)$ (Pilskaln et al. 1996). Particulate samples were collected in an acrylic sample tube attached to the base of the trap cone and pre-poisoned with a $4 \%$ density-adjusted formalin solution buffered to $\mathrm{pH} 7.9$ to 8.0 at $4^{\circ} \mathrm{C}$ (Pilskaln et al. 1996). Individual bi-weekly intervals were separated within the sample tube by layers of Teflon beads ( $410 \mu \mathrm{m}$ diameter) dispensed every $2 \mathrm{wk}$ from an intervalometer device suspended inside the trap cone (Anderson 1977, Pilskaln et al. 1996). A subset of these samples (November 1989, and June 1991 to September 1992) were analyzed for swimmers.

Processing and chemical analysis of the trap sam-

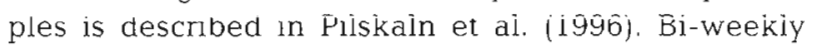
trap samples were gently wet sieved through a 410 $\mu \mathrm{m}$ Nitex screen, and swimmers removed from both size fractions (prior to detrital POC flux determinations) and examined microscopically. Swimmers were identified and counted from the entire $>410 \mu \mathrm{m}$ fraction, and from quantitative splits (Honjo-Erez rotary precision sample splitter; Honjo 1980, Pilskaln et al 1996) of the $<410 \mu \mathrm{m}$ fraction of each bi-weekly trap sample analyzed. The $>410 \mu \mathrm{m}$ fraction contained most of the swimmers, but represented less than $1 \%$ of the total mass flux of detrital material to the trap. Most of the zooplankton in the samples were intact, suggesting they entered the trap alive, with the exception of siphonophores, which were disassociated members (bracts and zooids) of colonies. However, some zooplankton may have died just prior to being trapped and would still appear intact (and thus could be included in the passive flux). Zooplankton were picked from trap samples using an Olympus SZH zoom stereo dissecting microscope with dark field illumination at 100 to $200 \times$ magnification, to ensure recognition of more cryptic swimmers (Michaels et al. 1990), then identified, measured, and counted. Swimmers were identified to major taxon, and occasionally to species level-particularly for those recognized from larvacean houses or other detrital communities (Steinberg et al. 1994, 1997) and thus deemed likely detrital associates.

Likely detrital associates included those groups or species commonly encountered on mesopelagic detritus in Monterey Bay (Steinberg et al. 1994, 1997) and on near-surface detritus in other studies (e.g. All- 
dredge 1972, 1976, Shanks \& Edmondson 1990, Ohtsuka \& Kubo 1991, Bochdansky \& Herndl 1992, Green \& Dagg 1997). These include the calanoid copepods Scopalatum vorax and Scolecithricella spp., poecilostomatoid copepods such as Oncaea spp. and Corycaeus spp., harpacticoid copepods such as Microsetella spp., polychaetes, and juvenile amphipods. These groups occur on many types of detritus (in addition to larvacean houses), and thus could have entered traps on other particle types as well. It was not possible to document whether these swimmers entered traps while associated with particles, as others have done (Shanks \& Edmondson 1990). However, we consider this list of zooplankton associates of marine detritus conservative, since these groups likely represent only a fraction of those that are possible detrital associates. For example, ostracods (Alldredge 1972, 1976, Shanks \& Edmondson 1990, Bochdansky \& Herndl 1992) and adult hyperiid amphipods (Harbison et al. 1977. Steinberg et al. 1994) have been noted to associate with marine snow, but we did not include them here.

Siphonophore parts were removed and counted in the total swimmer carbon, but not in the total number of swimmers. That is, we did not know how many bracts or zooids, which occurred in the traps, constituted a typical colony. Siphonophore wet weight was determined for samples containing large numbers of siphonophore zooids, and carbon determined from published relationships of carbon/wet weight ( $\mu \mathrm{g} \mathrm{C}=$ $0.004 \times \mu \mathrm{g}$ wet wt: Beers 1966).

Swimmer carbon was estimated from carbon/size relationships using published conversion factors as in Michaels et al. (1990) and Silver \& Gowing (1991). Conversion factors $\left(\mathrm{pg} \mathrm{C} \mathrm{mm}^{-3}\right.$ ) used were 0.08 for crustacea and fish, 0.02 for chaetognaths, 0.06 for pteropods, and 0.03 for polychaetes (see Table 11 in Parsons et al. 1984 and references therein), 0.004 for salps and doliolids (Madin et al. 1981), and 0.008 for other gelatinous zooplankton (Michaels et al. 1990). Larvacean carbon was estimated from tail length using: $\mathrm{C}(\mu \mathrm{g})=0.04 \times$ tail length $(\mathrm{mm})^{329}$ (Deibel 1986). Detrital particulate organic carbon (POC) in the trap samples was measured by the procedure described in Pilskaln et al. (1996) after zooplankton swimmers were microscopically removed from sediment samples. Percent organic carbon as swimmers in entire trap was calculated as (swimmer C/swimmer $\mathrm{C}+$ detrital C) $\times$ 100. To simplify our terminology, we use 'detrital carbon' to denote the non-swimmer material in the traps, although it includes substantial numbers of living microorganisms (Silver \& Gowing 1991, Silver et al. in press).

Traps are not meant to measure active animal-mediated fluxes (Silver et al. 1991), but for ease of comparison with detrital fluxes, we also express swimmer car- bon contribution in flux units of $\mathrm{mg} \mathrm{C} \mathrm{m} \mathrm{m}^{-2} \mathrm{~d}^{-1}$. Flux of swimmers cannot be considered quantitatively accurate, because of differential behavior of organisms in response to traps that results in biased species collection (Harbison \& Gilmer 1986, Michaels et al. 1990, Forbes et al. 1992).

\section{RESULTS}

In Monterey Bay, 1989 to mid 1991 are considered 'normal' upwelling years in which POC fluxes during spring upwelling were considerably higher than winter values. In 1992 POC fluxes at our site were reduced as a consequence of $\mathrm{El}$ Niño, resulting in smaller changes in flux from spring to winter (Chavez 1996, Pilskaln et al. 1996). Thus, we analyzed samples from a normal upwelling, high-flux period as well as samples from 1992 to ensure a representative data set. This is illustrated in samples from June and early July, 1991, showing high carbon flux, with lower fluxes during the rest of 1991 and 1992 (Fig. 1A). On average, $23.7 \%$ of the total POC in traps (detritus + swimmers) was due to the swimmer component (SE \pm 2.5, range 7.1 to 53.5) (Fig. $1 \mathrm{~B}$ ). From the swimmer component, the likely detrital associates averaged $1.5 \%$ of the trap $C$ (SE \pm 0.4 , range 0.1 to 11.4 ), and the other $22.2 \%$ of the trap $\mathrm{C}$ (SE \pm 2.3 , range 6.5 to 50.6) was due to other swimmers. Although giant larvaceans occurred in some of the samples (asterisks in Fig. 1B) (presumably increasing the probability that these samples would include zooplankton that entered traps while associated with their mucous houses), there appeared to be no more likely detrital associates in those samples (Fig. 1B).

There is no obvious seasonal pattern in total swimmer flux (Fig. 1). In addition, regression analyses showed no significant relationship between total swimmer C and detrital POC flux $(n=29, r=0.24, p>$ 0.05 ), or carbon flux due to detrital associates as a function of detrital POC flux $(n=29, r=0.10, p>0.05)$ (data not shown).

There were some qualitative seasonal patterns among individual groups within the swimmer assemblage. Numbers (and carbon contribution) of calanoid copepods and polychaetes peaked in trap samples in June-July (in both non-El Niño and El Niño years), while Oncaea spp. copepods were most numerous in traps in January-February. Other swimmer groups exhibited no obvious seasonality. There were no discernible differences in swimmer composition or contribution to flux between non-El Niño and El Niño years.

Calanoid copepods constituted the majority of the swimmers in the sediment trap samples. Many of the samples included the large hyperiid amphipods, Hype- 

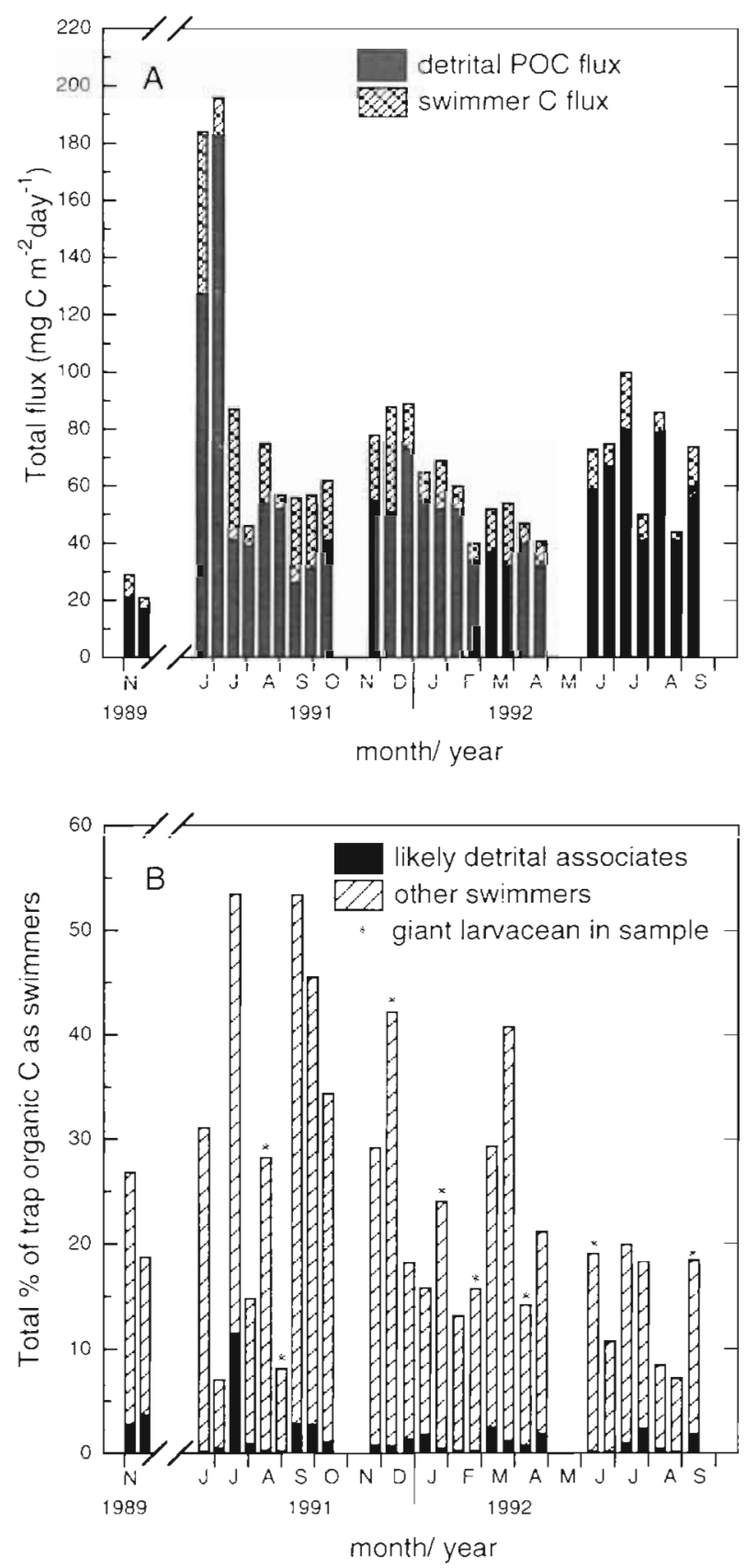

Fig. 1. (A) Bi-weekly detrital particulate organic carbon (POC) flux and swimmer carbon flux measured by sediment traps. (B) Percent swimmer carbon in sediment traps. Calculated as (swimmer C/swimmer C + detrital C) $\times 100$ (see Materials and methods'). $\mathrm{n}=29$ bi.-weekly samples from November 1989, and June 1991 through September 1992

ria medusarum hystrix. These amphipods were found in sediment traps deployed on the shelf break of the Beaufort Sea as well (Forbes et al. 1992). Other amphipods such as Phronima sp., and occasionally species of gammarid amphipods also occurred in the Monterey Bay trap samples. Adult amphipods occurred in low numbers (Fig. 2A), but accounted for the highest contribution of swimmer carbon in traps due to their large size (Fig 2B). We also found large numbers of juvenile amphipods that likely belong to the family Hyperiidae (R. Harbison pers. comm.). They may have emerged from the marsupium of one of the adult female amphipods, or they may be associated with detritus. These juvenile amphipods accounted for the highest mean number of swimmers per sample, with calanoid copepods a close second (Fig. 2A), but they contributed little carbon to the samples due to their tiny size (Fig. 2B). We have seen amphipods on marine detritus in Monterey Bay at mesopelagic depths via the video camera mounted on the submersible ROV, but they appear to escape upon collection of the detritus.

On average, the highest proportion of swimmers in traps were the calanoid copepods (e.g Calanus spp., Euchaeta spp., Eucalanus spp., Metridia spp.) (Fig. 2C). They also constituted the highest proportion of carbon contained in all the swimmers (Fig. 2D). Although the mean number of calanoid copepods and juvenile amphipods are nearly equal (Fig. 2A), the calanoid copepods constituted a greater proportion of the swimmers in each sample (Fig. 2C). This discrepancy results from the sporadic, but high numbers of juvenile amphipods versus the consistent presence of calanoid copepods in trap samples (i.e. \% total swimmers by number or by carbon was calculated first for each sample, then the mean \% was calculated). The same is true for the carbon contributed by adult amphipods and calanoid copepods (Fig. 2B, D): adult amphipods contributed considerable carbon to samples when present, but were not present as consistently as the calanoids.

Calanoid copepods that are detrital associates contributed little to traps, either in number or carbon content (Fig. 2A-D). Other copepods that we consider detrital associates (e.g. Corycaeus sp., and harpacticoid copepods such as Microsetella spp.) were rare. However, the poecilostomatoid copepod Oncaea spp. occurred in relatively high numbers, and made up a significant percentage $(>10 \%)$ of the swimmers (Fig. 2C). These copepods are small and do not make a significant carbon contribution to traps (Fig. 2B, D). Some copepods, most notably Euchaeta spp., entered traps with egg strings still attached

Other crustaceans such as ostracods and crustacean nauplii (both copepod and euphausiid) regularly occurred, but in low numbers and contributed little carbon to the traps. Euphausiid calyptopis stages occurred, but rarely was an adult present.

Gelatinous zooplankton such as chaetognaths, ctenophores (mostly Beroe sp.), medusae (e.g. Solmissus sp., Colobenema sp.), pteropods, larvaceans, salps, 


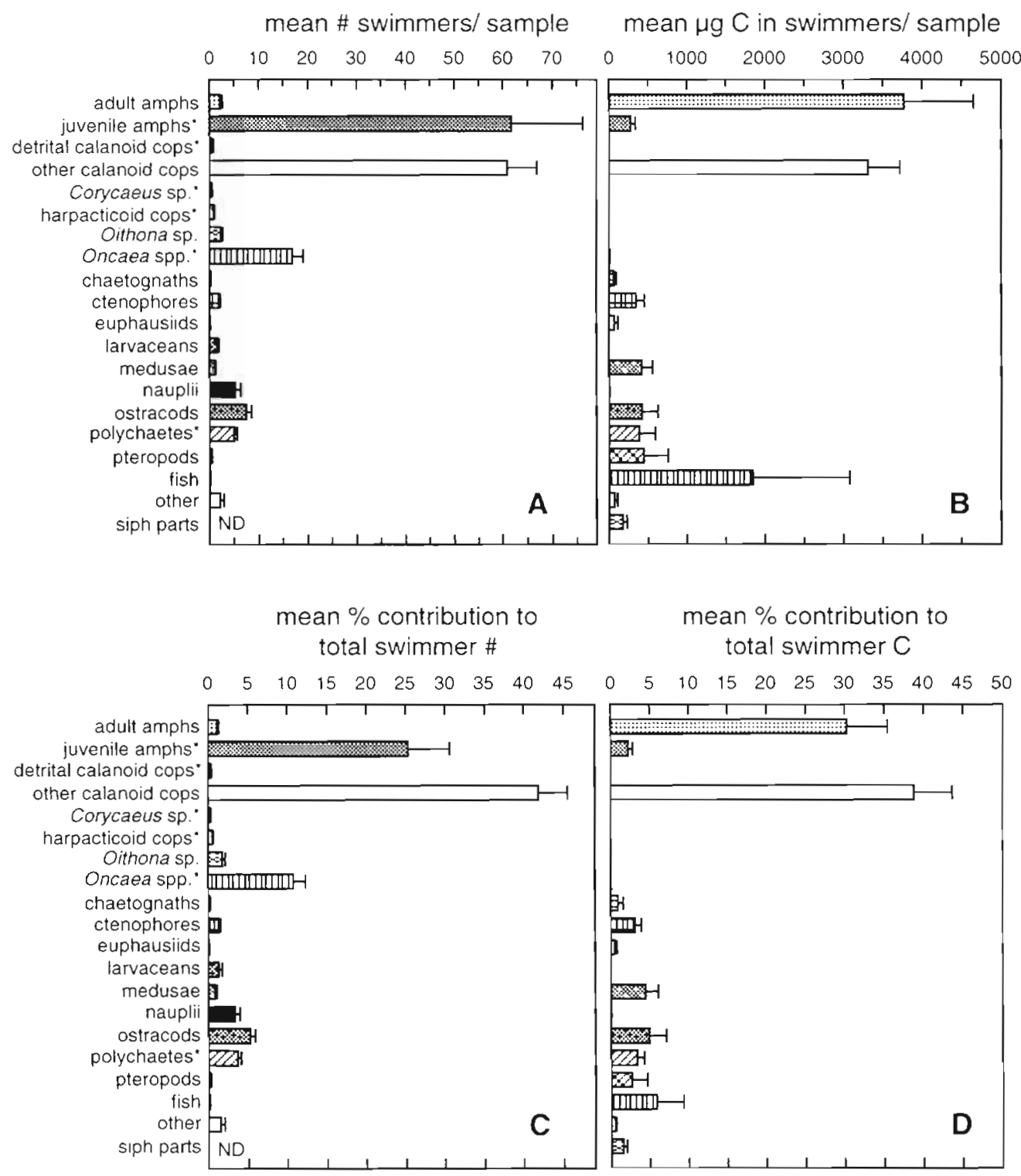

Fig. 2. Mean composition of the major swimmer groups/taxa removed from bi-weekly sediment trap samples. Asterisk (*) indicates taxa we consider likely detrital associates. Amphs: amphipods; cops: copepods; detrital calanoid cops: includes Scopalatum vorax, Scolecithricella sp. (see 'Materials and methods'); other: includes juvenile ophioroids, salps, Poeobious sp. (worm), and isopods; siph parts: siphonophore parts. ND: not determined. $n=29$ bi-weekly samples; error bars show +1 SE. Note: 2 C, 2 D calculated as no. or C in group/total no. or C in all swimmers

and some polychaetes (Tomopteris spp., Poeobius meseres) and zooids of siphonophores (e.g. gastrozooids, bracts) regularly occurred in traps but did not contribute much, by number or carbon content (Fig. 2A-D). Giant larvaceans, both Bathochordaeus sp. and Fritillarid types, were noted in some of the samples, and their houses were present.

Polychaete larvae were a conspicuous component of the swimmer assemblage. Most had full guts containing a greenish-brown mass. Light-microscope examination of their guts revealed many were filled with detritus, including tests of tintinnids and foraminifera, fecal pellets, crustacean parts, and diatoms. Similar food items were found in the mid-water polychaete Poeobius meseres in Monterey Bay (Uttal \& Buck 1996) and in the copepod Scopalatum vorax, which occurs on the giant larvacean houses in our study area (Steinberg 1995). Polychaete scales, easily mistaken for small fish scales, were also common in some samples.

Large, rare swimmers such as myctophid fish occasionally contributed a significant amount of swimmer carbon to traps (Fig. 2B). 
mean $\%$ contribution of swimmer $C$ to total trap organic C

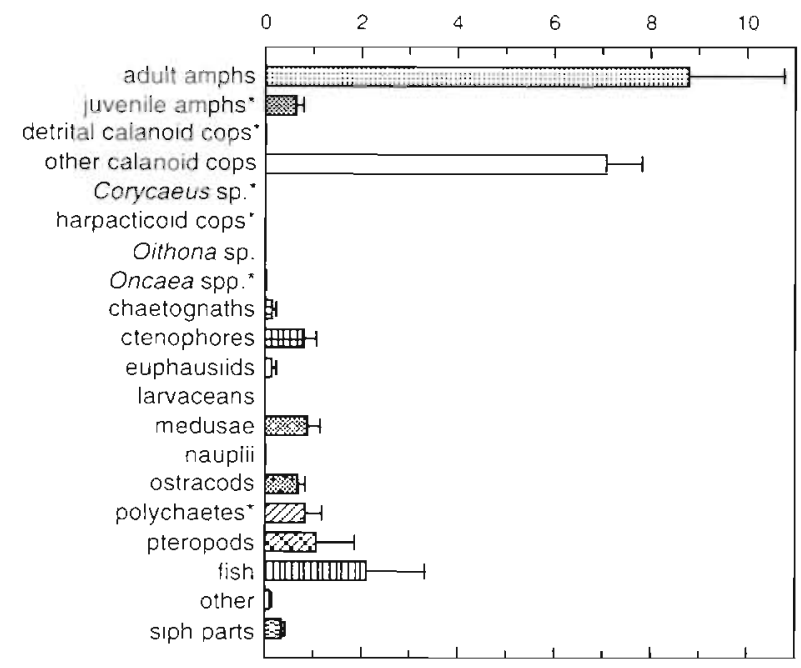

Fig. 3. Mean percent contribution of swimmer $C$ in sediment traps for the major swimmer taxa removed from bi-weekly sediment trap samples. Calculated as (swimmer C/swimmer $C+$ detrital C) $\times 100$ (see text). Asterisk (*) indicates taxa we consider likely detrital associates. Amphs: amphipods; cops: copepods; detrital calanoid cops: includes Scopalatum vorax, Scolecithricella sp. (see 'Materials and methods'); other: includes juvenile ophioroids, salps, Poeobious sp. (worm), and isopods; siph parts: siphonophore parts. $n=29$ bi-weekly samples; error bars show $+1 \mathrm{SE}$

Fig. 3 shows the mean percent contribution of swimmer carbon to trap POC, broken down by group. Adult amphipods account for the highest percent of the swimmer carbon in traps, averaging $8.8 \%$ of the carbon in the entire sample, followed by 'other' calanoid copepods $(7.1 \%)$, and fish $(2.1 \%)$. The remaining groups each make up $<2 \%$ of the POC in the traps. As illustrated in Fig. 1B, the combined groups we consider detrital associates (asterisks in Fig. 3) account for a mean of $1.5 \%$ of the POC in the Monterey Bay trap samples.

\section{DISCUSSION}

\section{Detritus and the deep-sea zooplankton community}

Detritus is presumed to be an important food source for the mid-and deep-water zooplankton community (e.g. Gowing \& Wishner 1992, Steinberg 1995, Uttal \& Buck 1996). Some zooplankton may ingest entire particles when they encounter them, and have no longerterm association, while others might spend much of their lives associated with particles, using them as a habitat, food source, or refuge from predators. Large, fast-sinking particles that transport fresh material may be the most nutritious, and association with these may be particularly beneficial. This association is likely an important part of the deep-sea ecology of zooplankton, and one might expect zooplankton to be adapted to live and feed on particles (e.g. adaptations of mouthparts, to chemical conditions, etc.) (Steinberg 1995). As a consequence of this association, zooplankton that are consistently associated with sinking detritus will likely enter sediment traps. What is unknown is how much these zooplankton may contribute to the sinking particle pool.

\section{Mass flux estimates: rationale for removal or inclusion of zooplankton swimmers}

'Swimmers' are a long-recognized problem in sediment trap research (reviewed in Knauer \& Asper 1989). They are normally assumed to be accidentally collected by traps, and thus not part of the true rain of non-living particulate matter. In this paper we were concerned with whether a major fraction of the zooplankton found in sediment traps are closely associated with sinking detritus and responsibie for particie degradation. Such organisms may be legitimately included in flux estimates, as their carbon derives from the particles they degrade and with which they permanently associate (Shanks \& Edmondson 1990, Silver \& Gowing 1991). It is customary to include the smaller microbial community (e.g. bacteria, radiolarians) in the flux as many are known decomposers and are too small to remove (Gowing 1986, Silver \& Gowing 1991). Sufficient attention has not been paid to some of the larger metazoans that likewise are part of the particle-associated community of decomposers. Our knowledge of these metazoan decomposer communities is still limited, but direct observations of detritus-associated zooplankton allow us to begin to distinguish those that are part of the vertical flux and those that are contaminating swimmers (Alldredge 1972, 1976. Shanks \& Edmondson 1990, Ohtsuka \& Kubo 1991, Bochdansky \& Herndl 1992, Steinberg et al. 1994, 1997. Green \& Dagg 1997).

Silver \& Gowing (1991) discuss the following spectrum of living organisms ranging from appropriate to inappropriate for inclusion in the particle flux: microbial and metazoan decomposer communities, moribund or dead organisms, non-motile life history stages such as eggs, vertical migrators, and active intruders attracted to traps. If zooplankton on sinking particles are at the top of a trophic pyramid beginning with bacteria and other microorganisms on detritus, they are simply larger remineralizers and could be considered part of the flux (Silver et al. 1991). However, if they use the particles only as resting sites, as refuge from predators, or for transport they should not be included in the flux. 


\section{Swimmer composition}

Our results indicate that 7 to $53 \%$ (mean $24 \%$ ) of the POC in traps is attributable to swimmers. This is in the range of what others have found: for example, Knauer et al. (1984) found a mean of $39 \%$ of the total carbon flux was swimmer carbon in formalin-preserved, $150 \mathrm{~m}$ traps in the Pacific off Mexico. Miquel et al. (1994) found that swimmers in their deep sediment trap $(1000 \mathrm{~m})$ in the Mediterranean Sea generally were one-third of the mass of the collected particles. However, their shallower $(80 \mathrm{~m}$ and $200 \mathrm{~m}$ ) traps contained swimmers that averaged twice the weight of the passive flux. Similarly, shallower (100 m) traps in the Arctic Ocean contained mostly macrocrustacean swimmers that made up 66 to $98 \%$ of the total C in the traps (Hargrave et al. 1989). Organismal contamination appears to decrease in importance with increasing depth (Michaels et al. 1990, Silver et al. 1991), thus the observed flux gradient with depth (e.g. Martin et al. 1987) may be less than previously thought (Michaels et al. 1990).

We found some similarities between the taxa in the Monterey Bay traps and those found in other studies. The most common zooplankton in the Monterey Bay traps (by number and by carbon) were the calanoid copepods (e.g. Calanus spp., Euchaeta spp., Eucalanus spp., Metridia spp.). Calanoid copepods and pteropods (shelled thecosomes) were the most common swimmers reported in $200 \mathrm{~m}$ traps deployed in the Beaufort Sea (Forbes et al. 1992) and in $1000 \mathrm{~m}$ traps in the Mediterranean Sea (Miquel et al. 1994). Similarly, copepods, ostracods, and pteropods together made up 70 to $90 \%$ of the swimmers (by number) in $600 \mathrm{~m}$ traps deployed south of Iceland (Gislason \& Asithorsson 1992). Gislason \& Asithorsson (1992) also report numerous ovigerous female Euchaeta sp., which we found too. Oncaea conifera (poecilostomatoida), an associate of deep-water detritus in Monterey Bay and present in our sediment traps, occurred in the deep Iceland traps as well. Calanoid copepods (e.g. Calanus spp., Metridia sp.), along with unidentified hyperiid amphipods, were also the most numerous swimmers in $100 \mathrm{~m}$ traps deployed in the Arctic Ocean (Hargrave et al. 1989).

The hyperiid amphipod Hyperia mesudarium, known to associate with scyphomedusae, has also been found in other sediment traps (Forbes et al. 1992). Other amphipods (Phronima sedentaria) were also prevalent in shallower ( 80 and $200 \mathrm{~m}$ ) traps in the Mediterranean Sea (Miquel et al. 1994).

Polychaete larvae were other important swimmers in the Monterey Bay traps and their gut contents suggest they feed on detritus. Using sediment traps with attached cameras, Shanks \& Edmondson (1990) found polychaete larvae to be strongly associated with marine snow, showing that sinking aggregates may transport larval meroplankton to the benthos. Polychaete larvae were also occasionally found in sediment traps along the Beaufort Sea shelf break (Forbes et al. 1992). In addition, Gardner et al. (1983) mention a worm that entered their (unpoisoned) sediment traps and fed on detritus, and that similar worms have been found in other traps in the region.

\section{Flux due to detrital associates}

We estimate an average of $1.5 \%$ of the POC in the Monterey Bay traps is contributed by metazoan detrital associates. This is a small percentage of the total POC flux, and we can conclude that even the removal of swimmers that are decomposers would likely not introduce much ambiguity to trap-flux measurements in this area. Important factors considered in the interpretation of these results are (1) our limited knowledge of the zooplankton decomposer community at mesopelagic depths, (2) the relative contribution of zooplankton on detritus to sediment trap C in low-vs highflux environments, and (3) zooplankton behavior on encountering a trap. We consider these in turn below.

First, our selection of detrital associates could lead to underestimates of the actual metazoan decomposer community on particles. We only included groups that are currently known to associate with detritus; yet unknown taxa likely exist. Indeed, we did not collect taxa that are loosely associated or that escape during collection, so bias is likely towards undersampling. One example of 'visitors' to detritus are the adult hyperiid amphipods. We were cautious about adding these to the list of detrital associates, as the extent of their particle use is still not clear. Hyperiid amphipods accompany gelatinous zooplankton (Harbison et al. 1977, Laval 1980), and have been reported to associate with (Harbison et al. 1977) and consume (Lampitt et al. 1993) marine snow. We sporadically found (and observed via the ROV) hyperiid amphipods on giant larvacean houses, occasionally in high numbers (Steinberg et al. 1994). If we add carbon from adult hyperiid amphipods ( $-9 \%$ of carbon in trap, Fig. 3 ) to the carbon contributed by detrital associates, $10 \%$ of the carbon in the trap would be due to detrital associates.

Second, our study was conducted in a coastal area of relatively high productivity and flux (Chavez 1996, Pilskaln et al. 1996). In lower flux regimes, such as oligotrophic gyres, swimmers may constitute a more or less important proportion of the carbon flux, as zooplankton are associated with detritus in these areas as well (Steinberg pers. obs. in the Sargasso Sea). A comparison of live microorganisms (algae and protozoans) in 
the vertical particle flux between oligotrophic and eutrophic waters in the Pacific shows flux of these organisms is positively correlated with primary production in overlying waters, although the relationship was weak and dependent on the inclusion of results from a single upwelling site (Silver \& Gowing 1991). Little information is available on how zooplankton swimmer biomass differs between high-and low-flux environments, but a few seasonal studies exist. Hargrave et al. (1989) report lower proportions of macrocrustacean swimmers in traps during higher POC and PON flux periods in the Arctic Ocean. However, Michaels et al. (1990) found both the vertical pattern and magnitude of swimmer carbon flux was constant over a series of seasonal trap deployments in the Pacific Ocean. Further study on swimmer composition with depth and in different flux regimes is needed to assess the degree to which detritus-associated zooplankton affect flux measurements in other environments.

Lastly, behavior of many zooplankton taxa when they encounter a sediment trap is poorly known and likely complex, and will affect which taxa are collected. Thus traps can act as attractants or barriers (Harbison \& Gilmer 1986), preferentially including those organisms not associated with detritus, or excluding some taxa that may have entered a trap associated with particles, but then escaped. Examples of organisms that are more susceptible to collection by sediment traps include the pteropods (Harbison \& Gilmer 1986). When disturbed, as occurs when pteropods contact a trap, they respond by sinking rapidly, causing them to be preferentially collected by traps. Colonial radiolarians also exhibit sinking behavior when mechanically disturbed (Swanberg 1979). Peterson \& Dam (1990) suggest the high number of Temora longicornus they found in trap samples is likely due to their hop and sink swimming behavior: they are killed when they sink into the toxic brine in traps. Even the behavior of microorganisms, such as the vertical migration of some dinoflagellates and ciliates, can cause them to be preferentially collected by sediment traps (Heiskanen 1995)

Here, we are most concerned with the undersampling by traps of zooplankton that are associates of detritus. There are a number of reasons to believe large particles like giant larvacean houses may be undersampled by particular sediment trap designs (Silver et al. in press). For example, baffles at the mouth of a trap could entrap sticky houses or cause them to slide off, preventing them from entering. If so, when large aggregates fall near the mouth of a trap, associated zooplankton may have an opportunity to escape before the aggregate descends into the trap, or they might 'bounce' off the surface of the trap along with the aggregate. Associates of smaller, more typical marine snow particles may not experience the problem as frequently if the particles and associated zooplankton are small enough to pass through baffles without contacting them.

\section{CONCLUSION}

Sediment traps measure flux of both detrital particles and living organisms (Silver \& Gowing 1991). The microbial contribution to flux has been studied previously. Bacterial associates typically constitute a few percent of the carbon in sediment traps (e.g. Ducklow et al. 1985, Taylor et al. 1986). Larger, protozoan decomposers can account for greater than $10 \%$ of the carbon flux in traps (Gowing 1986, Silver \& Gowing 1991). Our results indicate that larger, metazoan associates of detritus also occur in sediment traps, and traps may be a good alternative collection device for studying some of these species (e.g. polychaetes). We determined there is a 'swimmer' fraction that is closely associated with detritus and analogous to the microbiai populations that accompany sinking particles into traps: these could arguably be considered part of the flux. These zooplankton associates of detritus average just a few percent of the POC flux, however, and thus do not affect measurements of carbon flux significantly in Monterey Bay. The degree to which these detritusassociated zooplankton affect flux estimates will likely vary with the environment and the composition of the local detrital community. Future studies of other environments, and our increasing knowledge about the true associates of detritus, will help us understand how these larger members of the detrital community affect the estimates of midwater particle flux made by sediment traps.

Acknowledgements. Special thanks to the captain and crew of the RV 'Pt. Sur' for assistance with sediment trap moonng deployments and recoveries We thank the captain, crew, and especially the ROV pilots, J. McFarlane, C. Grech, and C. Dawe, of the RV 'Pt. Lobos' for help with sample collection. We are grateful to Jenny Paduan and Susan Coale for techn1cal assistance, and to Richard Harbison for amphipod identification. Anthony Michaels, David Malmquist, and 3 anonymous reviewers made helpful suggestions and comments on the manuscript. This work was funded by NSF grant OCE9301892 to M.W.S., and NSF grant OCE-9015602 and funding at the Monterey Bay Aquarium Research Institute from the David and Lucille Packard Foundation awarded to C.H.P.

\section{LITERATURE CITED}

Alldredge AL (1972) Abandoned larvacean houses: a unique food source in the pelagic environment. Science 117 $885-887$ 
Alldredge AL (1976) Discarded appendicularian houses as sources of food, surface habitats, and particulate organic matter in planktonic environments. Limnol Oceanogr 21. $14-23$

Anderson RY (1977) Short-term sedimentation response in lakes in western United States as measured by automated sampling. Limnol Oceanogr 22:423-433

Beers JR (1966) Studies on the chemical composition of the major zooplankton groups in the Sargasso Sea off Bermuda. Limnol Oceanogr 11:520-528

Bochdansky AB, Herndl GJ (1992) Ecology of amorphous aggregations (marine snow) in the Northern Adriatic Sea. III. Zooplankton interactions with marine snow. Mar Ecol Prog Ser 87:135-146

Chavez FP (1996) Forcing and biological impact of onset of the 1992 El Nino in central California. Geophys Res Lett 23:265-268

Deibel D (1986) Feeding mechanism and house of the appendicularian Oikopleura vanhoeffeni. Mar Biol 93:429-436

Ducklow HW, Hill SM, Gardner ND (1985) Bacterial growth and the decomposition of particulate organic carbon collected in sediment traps. Cont Shelf Sci 4:445-464

Forbes JR, Macdonald RW, Carmack EC, Iseki K, O'Brien MC (1992) Zooplankton retained in sequential sediment traps along the Beaufort Sea shelf break during winter Can J Fish Aquat Sci 49:663-670

Gardner WD, Hinga KR, Marra J (1983) Observations on the degradation of biogenic material in the deep ocean with implications on the accuracy of sediment trap fluxes J Mar Res 41:195-214

Gislason A, Asithorsson OS (1992) Zooplankton collected by sediment trap moored in deep water south of Iceland Sarsia 77:219-224

Gowing MM (1986) Trophic biology of phaeodarian radiolarians and flux of living radiolarians in the upper $2000 \mathrm{~m}$ of the North Pacific central gyre. Deep Sea Res 33:655-674

Gowing MM, Wishner KF (1992) Feeding ecology of benthopelagic zooplankton on an eastern tropical Pacific seamount. Mar Biol 112:451-467

Green EP, Dagg MJ (1997) Mesozooplankton associations with medium to large marine snow aggregates in the northern Gulf of Mexico. J Plankton Res 19:435-447

Harbison GR, Biggs DC, Madin LP (1977) The associations of Amphipoda Hyperiidea with gelatinous zooplankton-II Associations with Cnidaria, Ctenophora and Radiolaria Deep Sea Res 24:465-488

Harbison GR, Gilmer RW (1986) Effects of animal behavior on sediment trap collections: implications for the calculation of aragonite fluxes. Deep Sea Res 33:1017-1024

Hargrave BT, von Bodungen B, Conover RJ, Fraser AJ, Phillips G, Vass WP (1989) Seasonal changes in sedimentation of particulate matter and lipid content of zooplankton collected by sediment trap in the Arctic Ocean off Axel Heiberg Island. Polar Biol 9:467-475

Heiskanen AS (1995) Contamination of sediment trap fluxes by vertically migrating phototrophic micro-organisms in the coastal Baltic Sea. Mar Ecol Prog Ser 122:45-58

Honjo S (1980) Material fluxes and modes of sedimentation in the mesopelagic and bathypelagic zones. J Mar Res 38 $53-97$

Karl DM, Knauer GA (1989) Swimmers: a recapitulation of the problem and a potential solution. Oceanography 2:32-35

Knauer GA, Asper V (1989) Sediment trap technology and sampling. U.S. GOFS Planning Report no. 10. U.S. GOFS Planning Office, Woods Hole, MA, p 94

Knauer GA, Karl DM, Martin JH. Hunter CN (1984) In-sith effects of selected preservatives on total carbon, nitrogen, and metals collected in sediment traps. J Mar Res 42 : $445-462$

Knauer GA, Martın JH, Bruland KW (1979) Fluxes of particulate carbon, nitrogen, and phosphorus in the upper water column of the northeast Pacific. Deep Sea Res 26:97-108

Lampitt RS, Wishner KF, Turley CM, Angel MV (1.993) Marine snow studies in the Northeast Atlantic Ocean: distribution, composition and role as a food source for migrating plankton. Mar Biol 116:689-702

Laval P (1980) Hyperiid amphipods as crustacean parasitoids associated with gelatinous zooplankton. Oceanogr Mar Biol Annu Rev 18:11-56

Lee C, Wakeham SG, Hedges JI (1988) The measurement of oceanic particle flux-are 'swimmers' a problem? Oceanography 1:34-36

Madin LP. Cetta CM, MCAllister VI (1981) Elemental and biochemical composition of salps (Tunicata: Thalacia). Mar Biol 63:217-226

Martin JH, Knauer GA, Broenkow WW (1987) VERTEX: carbon cycling in the northeast Pacific. Deep Sea Res 34 : 329-352

Michaels AF, Silver MW, Gowing MM, Knauer GA (1990) Cryptic zooplankton 'swimmers' in upper ocean sediment traps. Deep Sea Res 37:1285-1296

Miquel JC, Fowler SW, La Rosa J, Buat-Menard P (1994) Dynamics of the downward flux of particles and carbon in the open northwestern Mediterranean Sea. Deep Sea Res 41:243-261

Ohtsuka S, Kubo N (1991) Larvaceans and their houses as important food for some pelagic copepods. Proc 4th Int Conf Copepoda. Bull Plankton Soc Jpn, Spec Vol: $535-551$

Parsons TR, Takahashi M. Hargrave B (1984) Biological oceanographic processes. Pergamon Press, Oxford

Peterson WT, Dam HG (1990) The influence of copepod swimmers on pigment fluxes in brine-filled vs. ambient seawater-filled sediment traps. Limnol Oceanogr 35:448-455

Pilskaln CH, Paduan JB, Chavez FP, Anderson RY, Berelson WM (1996) Carbon export and regeneration in the coastal upwelling system of Monterey Bay, central California. J Mar Res 54:1149-1178

Shanks AL, Edmondson EW (1990) The vertical flux of metazoans (holoplankton, meiofauna, and larval invertebrates) due to their association with marine snow. Limnol Oceanogr 35:455-463

Silver M, Pilskaln C, Steinberg D (1991) The biologists' view of sediment trap collections: problems of marine snow and living organisms. In: Wassman $\mathrm{P}$, Heiskanen $\mathrm{A}$, Lindahl O (eds) Sediment trap studies in the Nordic countries, Vol 2. Symp Proc, NurmiPrint Oy, Nurmijärvi, p 76-93

Silver MW, Coale SL, Pilskaln $\mathrm{CH}$, Steinberg DK (in pressi 'Macro-snow': importance as community centers and agents of material flux in the mesopelagic zone. Limnol Oceanogr

Silver MW, Gowing MM (1991) The 'particle' flux: origins and biological components. Prog Oceanogr 26:75-113

Steinberg DK (1995) Diet of copepods (Scopalatum vorax) associated with mesopelagic detritus (giant larvacean houses) in. Monterey Bay, California. Mar Biol 122: $571-584$

Steinberg DK, Silver MW. Pilskaln CH (1997) The role of mesopelagic zooplankton in the community metabolism of giant larvacean house detritus in Monterey Bay, California, USA. Mar Ecol Prog Ser 147:167-179

Steinberg DK, Silver MW, Pilskaln CH, Coale SL, Paduan JB (1994) Mid-water zooplankton communities on pelagic detritus (giant larvacean houses) in Monterey Bay, Cali- 
fornia. Limnol Oceanogr 39(7):1606-1620

Swanberg NR (1979) The ecology of colonial radiolarians: their colony morphology, trophic interactions and associations, behavior, distribution, and the photosynthesis of their symbionts. PhD thesis, Woods Hole Oceanographic Institution

Editorial responsibiluty: Otto Kinne (Editor),

Oldendorf/Luhe, Germany
Taylor GT, Karl DM, Pace ML (1986) Impact of bacteria and zooflagellates on the composition of sinking particles: an in situ experiment. Mar Ecol Prog Ser 29:141-151

Uttal L, Buck KR (1996) Dietary study of the midwater polychaete, Poeobius meseres in Monterey Bay, California. Mar Biol 1.25:333-343

Submitted: June 23, 1997; Accepted: December 2, 1997 Proofs received from author(s): March 2, 1998 